УДК 930

DOI: $10.52575 / 2687-0967-2021-48-1-198-210$

\title{
Белгородский учительский институт в современной историографии
}

\author{
В.А. Лю-Ку-Тан \\ Белгородский государственный национальный исследовательский университет, \\ Россия, 308015, г. Белгород, ул. Победы, 85 \\ E-mail: lyu-ku-tan@bsu.edu.ru
}

\begin{abstract}
Аннотация. Данное исследование представляет собой обобщение и систематизацию исследовательского опыта, анализ историографии 2000-2010-х годов, посвященной созданию и функционированию Белгородского учительского института в конце XIX - начале XX вв. В статье представлено количество научных публикаций, которые разделены на два периода по уровню публикационной активности. Изучены причины увеличения исследовательского интереса к истории Белгородского учительского института. По результатам анализа содержания научные публикации разделены на ряд тематических блоков: исследования нормативно-правовой базы, регламентирующей открытие и деятельность Белгородского учительского института, его место в системе педагогического образования Российской Империи; реконструкция и изучение биографий и научной деятельности директоров, преподавателей и выпускников учительского института; изучение повседневной жизни воспитанников городского училища при учительском институте.
\end{abstract}

Ключевые слова: историография, Белгородский учительский институт, городское училище, Министерство Народного Просвещения, образование.

Для цитирования: Лю-Ку-Тан В.А. 2021. Белгородский учительский институт в современной историографии. Via in tempore. История. Политология, 48 (1): 198-210. DOI: $10.52575 / 2687-0967-2021-48-1-198-210$.

\section{Belgorod Teacher's Institute in contemporary historiography}

\author{
Viktoria A. Lyu-Ku-Tan \\ Belgorod National Research University, \\ 85 Pobeda St., Belgorod, 308015, Russia \\ E-mail: lyu-ku-tan@bsu.edu.ru
}

\begin{abstract}
This study presents generalization and systematization of research experience, an analysis of the 2000s - 2010s historiography, dedicated to the Belgorod Teacher's Training Institute's foundation and functioning. The article presents the number of scientific publications, which are divided into two periods by the level of publication activity. Also the reasons of the increase of research interest in the history of the Belgorod Teacher's Training Institute have been studied. Scientific publications were divided into a number of thematic blocks according to the analysis of its content: research of the legal framework governing the opening and activities of the Belgorod Teacher's Training Institute, its place in the system of pedagogical education of the Russian Empire; reconstruction and study of biographies and scientific activities of directors, teachers and graduates of the teacher's training institute; study of the scholar's daily life and the city school by the teacher's training institute.
\end{abstract}

Keywords: historiography, Belgorod Teacher's Training Institute, town school, Ministry of Public Education, education. 
For citation: Lyu-Ku-Tan V.A. 2021. Belgorod Teacher's Institute in contemporary historiography. Via in tempore. History and political science, 48 (1): 198-210 (in Russian). DOI: $10.52575 / 2687-0967-2021-48-1-198-210$.

Изучение и использование исторического опыта подготовки педагогов является одним из аспектов успешной модернизации современной системы образования и повышения его уровня, в связи с этим в современной исторической науке наблюдается увеличение исследовательского интереса к учительским институтам Российской Империи.

Наиболее крупный сегмент в современной историографии учительских институтов представлен локальными исследованиями, среди которых можно выделить работы, посвященные нескольким учительским институтам одного региона. Наиболее изученными в данном аспекте на сегодняшний день являются учительские институты Западной и Восточной Сибири, Южного Урала [Кочурина, 2005; Шагеева, 2014; Шилов 2014], а также исследования, нацеленные на выявление особенностей создания и функционирования одного конкретного учительского института [Мустафина и др., 2014; Костылева, 2020].

На сегодняшний день одним из наиболее исследованных учительских институтов европейской части Российской Империи является Белгородский учительский институт. С целью продолжения дальнейшего комплексного изучения данной темы необходимо определить степень её изученности в современной исторической науке. Данное исследование представляет собой анализ историографии 2000-2010-х годов, посвященной созданию и функционированию Белгородского учительского института, с целью обобщения и систематизации исследовательского опыта современных учёных.

Основу методологической базы исследования составили общенаучные методы метод анализа, синтеза, а также проблемно-хронологический метод, использование которого позволило проанализировать исследования, посвященные изучению Белгородского учительского института в хронологической последовательности, а также выделить проблемные историографические блоки.

По результатам изучения исследований, посвященных истории Белгородского учительского института, было установлено, что в основном они представлены научными статьями и краткими историческими справками в монографиях по истории Белгородского государственного университета, а также была составлена таблица, которая позволила проследить динамику публикационной активности по указанной теме.

Таблица 1

Table 1

Количество опубликованных исследований по истории Белгородского учительского института с 1999 по 2019 гг.

The number of published studies on the history of the Belgorod Teachers' Institute 1999-2019

\begin{tabular}{|c|c|}
\hline Год & Количество публикаций \\
\hline 1999 & 1 \\
\hline 2001 & 1 \\
\hline 2002 & 1 \\
\hline 2007 & 1 \\
\hline 2013 & 1 \\
\hline 2014 & 4 \\
\hline 2016 & 8 \\
\hline 2017 & 5 \\
\hline 2018 & 7 \\
\hline 2019 & 3 \\
\hline
\end{tabular}


С 1999 по 2019 гг. было опубликовано 32 исследования по истории учительского института в Белгороде. Основываясь на анализе роста публикационной активности, можно говорить о двух периодах: с 1999 по 2013 гг. и с 2014 по 2019 гг.

Историография первого периода посвящена изучению становления и функционирования учительского института в Белгороде до 1917 г. и характеризуется тенденцией появления исследований, актуальность которых обусловлена празднованием юбилейных дат Белгородского государственного университета [Дятченко, 2007].

В 1999 г. вышло исследование Е.Ю. Прокофьевой, в котором реконструирована деятельность Белгородского учительского института до революционных событий 1917 г. Историком изучены учебный процесс, преподавательский состав и вместе с тем отмечена проблема материального положения преподавателей учебного заведения. Е.Ю. Прокофьева рассматривает городское училище. Исследован социальный состав учеников городского училища и воспитанников учительского института, а также правила пребывания их в учебном заведении. В статье указаны основные положения реформы учительских институтов, предпринятой Временным правительством в 1917 г., которой должен был подвергнут и Белгородский учительский институт [Прокофьева, 1999].

Значительное увеличение исследовательского интереса к истории Белгородского учительского института наблюдается с 2014 г. и обусловлено следующими факторами: вопервых, в связи с развитием цифровых технологий у современных ученых появился доступ к цифровым копиям многих источников конца XIX - начала XX века из фондов архивов и библиотек [Московкин, 2016, с. 22], во-вторых, в процессе реализации проекта «Модернизация Музея истории университета», в связи с отсутствием данных в архивах Белгородской области, у сотрудников музея появилась возможность проводить научноисследовательскую и поисковую работу в фондах архивов, библиотек и музеев России [Денисова, 2018, с. 78]. Наибольшее количество - 8 исследований - вышло в 2016 году, в год празднования 140-летия Белгородского государственного национального исследовательского университета.

К 140-летнему юбилею Белгородского государственного национального исследовательского университета, который является правопреемником Белгородского учительского института, вышел ряд работ, посвященных истории становления и работы учительского института в Белгороде [Мамаева, 2016; Московкин, 2016; Новый этап, 2016; Терещенко, 2016].

Следует отметить, что увеличение исследовательского интереса и актуализация исследований учительских институтов привели к расширению тематики научных работ. Наряду с исследованием истории становления и основных этапов исторического развития Белгородского учительского института современные ученые также изучают нормативноправовую базу, регламентирующую деятельность учительских институтов, место Белгородского учительского института в системе педагогического образования Российской Империи, вопрос открытия учительского института в г. Белгороде, биографии и научную деятельность директоров, преподавателей и выпускников учительского института, повседневную жизнь воспитанников, а также вопрос о здании и городском училище при учительском институте.

Нормативно-правовая база. Рассматривая нормативно-правовую базу, регламентирующую деятельность как учительских институтов в целом, так и Белгородского учительского института в частности, значительное внимание исследователи уделяют следующим источникам: «Положение о городских училищах и учительских институтах» (1872), «Инструкция о порядке управления учительскими институтами» (1876), «Программы и учебные планы предметов, преподаваемых в учительских институтах» (1876), «Инструкция касательно объема и метода преподавания учебных предметов в учительских институтах» (1876). В 2001 г. А.М. Болгова выпустила систематизированный сборник нормативно-правовых актов второй половины XIX в., регулирующих работу учительских ин- 
ститутов [Болгова, 2001]. Другие исследователи рассмотрели процесс поступления в Белгородский учительский институт и городское училище и проанализировали программу вступительных экзаменов по Закону Божиему [Денисова, Лю-Ку-Тан, 2018а]. Авторы отмечают, что, несмотря на установленные унифицированные правила и программы поступления в 1876 г. Министерством Народного Просвещения, они могли варьироваться в различных учительских институтах [Денисова, Лю-Ку-Тан, 2016].

Опираясь на нормативно-правовую базу, современные исследователи изучили причины создания и специфику работы Белгородского учительского института в системе педагогического образования Российской Империи. В исследовании Д.А. Терещенко изучены роль и место учительских институтов в системе профессиональной подготовки педагогов на рубеже XIX - XX вв., а также представлено развитие и изменение сети учительских институтов на территории Российской Империи в хронологическом аспекте. Автор рассматривает деятельность учительского института в период с 1876 по 1917 годы, в том числе программы преподаваемых предметов, преподавательский состав, количество воспитанников и их сословную принадлежность, ошибочно относя его к учебным заведениям, предоставляющим «незаконченное высшее специальное образование» [Терещенко, 2016, c. 154].

В современной историографии проанализирован процесс учреждения Белгородского учительского института. В работах А.М. Болговой и И.В. Денисовой рассмотрен процесс торжественного открытия учебного заведения 26 сентября 1876 г., указано количество воспитанников и учеников, принятых в учительский институт и городское училище соответственно, список первых преподавателей, сведения о здании, в котором располагались учебные заведения [Болгова, 2002; Денисова, 2013].

Директора Белгородского учительского института. С 2014 выходят комплексные исследования В.М. Московкина, посвященные директорам, преподавательскому составу и выпускникам учебного заведения. На основе опубликованных источников («Журнал Министерства народного просвещения», «Циркуляр по Харьковскому учебному округу», «Списки лиц, служащих по Харьковскому учебному округу») восстановлены списки преподавателей учительского института за 1876, 1886,1894, 1902, 1903, 1913 годы, а также представлены списки выпускников 1894, 1895, 1902, 1903 годов с информацией о назначении их на службу в городские и уездные училища Харьковского учебного округа. Используя историко-биографический метод при работе с указанными источниками и поисковой системой Google, автор реконструировал процесс профессионального развития и научные биографии пяти директоров учебного заведения: П.Е. Рощина, Д.Н. Ларионова, А.Ф. Комарова, Ф.Е. Пактовского, А.К. Димитриу [Московкин, 2014а, г, 2016].

В целом исследование биографии директоров Белгородского учительского института является одним из наиболее изученных аспектов в изучении истории учебного заведения. В.М. Московкин публикует отдельные работы, посвященные А.Ф. Комарову, П.Е. Рощину, А.К. Димитриу, структура которых включает в себя информацию о местах их службы, предшествующих учительскому институту или следующих за ним, а также данные на основе поиска в сети Интернет с помощью Google Books и Google Scholar об их научно-исследовательской работе [Московкин, 2014б, в, 2016; Рощин, 2016; Московкин, Садовски, 2016, 2018].

Значительное внимание исследователями уделено личности А.К. Димитриу. В работе И.В. Денисовой на основе неопубликованных источников изучен период обучения А.К. Димитриу в Императорском Новороссийском университете и его научная деятельность под руководством Ф.И. Успенского и Э.Р. фон Штерна. В данном исследовании реконструированы его профессиональная и научная биография. Анализируя работу А.К. Димитриу в должности директора Белгородского учительского института, И.В. Денисова особо отмечает его заслугу в подъеме уровня педагогического образования не только в учительском институте, но и в г. Белгороде в целом [Денисова, 2016б]. 
Обращаясь к реконструкции биографии А.К. Димитриу, В.М. Московкин публикует ряд документов (Отношение Белгородского педагогического кружка, диплом об окончании Императорского Новороссийского университета) и фотографий из семейного архива правнучки бывшего директора Белгородского учительского института Н.Л. Потаниной, на которых в том числе запечатлен преподавательский состав учебного заведения XX века [Московкин, 2017].

Преподаватели Белгородского учительского института. Наряду с реконструкцией биографии директоров Белгородского учительского института исследователи изучают и преподавательский состав, значительное внимание уделяется не только восстановлению списков преподавателей учебного заведения, но и исследованию их жизни, творчества, научной и педагогической деятельности. Одним из актуальных рассматриваемых вопросов является белгородский период жизни академика живописи и преподавателя рисования и черчения учительского института в Белгороде с 1876 по 1886 годы Юлия Ивановича Феддерса [Лимаров, Патлань, 2015; Денисова, 2016а].

В 2017 г. выходит исследование, посвященное законоучителям учебного заведения. По результатам изучения опубликованных источников и документов из фондов Российского государственного исторического архива и Государственного архива Белгородской области представлен анализ программ преподавания Закона Божия и восстановлены биографии 6 законоучителей: М.Н. Федорова, М.П. Трухманова, А.В. Гапонова, Л.Н. Булгакова, Е.Н. Попова, А.Г. Попова и учителя пения священника Н.В. Боголюбова; дается характеристика жизни, научному труду и образовательной деятельности во время их службы в Белгородском учительском институте [Денисова, Лю-Ку-Тан, 2018д]. В статье опубликованы фотографии трех законоучителей - М.П. Трухманова, Е.Н. Попова, А.Г. Попова.

Выпускники и воспитанники Белгородского учительского института. На сегодняшний день изучены правила приёма, анализ процесса обучения, образовательный уровень, сословная принадлежность, сценарий профессиональной жизни воспитанников Белгородского учительского института как будущих учителей городского училища и примеры их самореализации в других профессиональных областях [Денисова, Лю-Ку-Тан, 2019в].

Поднимая дискуссионный вопрос о литературном произведении как историческом источнике современные исследователи с целью изучения повседневной жизни поступающих и воспитанников Белгородского учительского института и города Белгорода обращаются к творчеству советского писателя Ивана Дмитриевича Василенко. «В 1914 г. И.Д. Василенко прибыл в город Белгород для поступления в Белгородский учительский институт. Белгородскому периоду жизни писателя посвящена его повесть «Волшебные очки» из цикла «Жизнь и приключения заморыша» (1962), где представлено описание учебного заведения и города Градобельска, так Иван Дмитриевич называет Белгород» [Денисова, Лю-Ку-Тан, 2019а, с. 173]. В научной статье представлены процесс поступления в учительский институт, сравнение сведений из официальных источников и повести о количестве поступивших и их сословной принадлежности в 1914 г., сопоставлены литературные герои и преподавательский состав.

На сегодняшний день продолжается изучение выпускников Белгородского учительского института. Исследователями восстановлено ежегодное количество выпускников учебного заведения с 1879 по 1916 годы, 75 \% из них удалось идентифицировать, по результатам работы с «Циркуляром по Харьковскому учебному округу» восстановлены списки выпускников учебного заведения с 1879 по 1912 годы [Золотая книга выпускников, 2016, с. 11-13]. В современной исторической науке продолжается работа по восстановлению биографий выпускников учительского института в исследовании И.В. Денисовой и В.А. Лю-Ку-Тан, в результате изучения и анализа документов из фондов Российского государственного исторического архива и Белгородского государственного историкокраеведческого музея и опубликованных источников реконструированы биографии и 
представлены фотографии выпускников Е.М. Подтягина, 3.И. Угрюмова, П.Ф. Бузука, А.Б. Петрищева. Кроме того, авторами были реконструированы биографии и проанализирована научная деятельность известных педагогов П.И. Барышникова и И.П. Кулегаева, которые окончили Белгородский учительский институт. В исследовании представлен анализ сохранившихся воспоминаний об учебном заведении известного публициста А.Б. Петрищева и М.М. Рыбалкина [Денисова, Лю-Ку-Тан, 2019б].

Анализу воспоминаний и реконструкции биографии выпускника Белгородского учительского института 1897 г. М.М. Рыбалкина посвящено исследование М.В. Московкина и И.Т. Шатохина. В работе детально описана рукопись с воспоминаниями об учительском институте, хранящаяся в фондах Белгородского государственного историкокраеведческого музея. В исследовании опубликованы воспоминания о здании Белгородского учительского института, меню, учебном процессе, директоре Д.Н. Ларионове и преподавателях, в том числе проведен сравнительный анализ списка преподавателей и служащих 1894 г. из справочных источников и рукописи [Московкин, Шатохин, 2017].

Повседневная жизнь воспитанников Белгородского учительского института. Используя практические и теоретические наработки такого направления, как история повседневности, современные исследователи обращаются к реконструкции сценария жизни воспитанника Белгородского учительского института. По результатам анализа нормативно-правовых актов, регламентирующих процесс поступления и дальнейшего обучения и пребывания воспитанников в институте, неопубликованных отчетов директоров Белгородского учительского института из фондов Российского государственного исторического архива и воспоминаний выпускников восстановлены: описание зданий, где проживали и обучались воспитанники, распорядок дня, рацион питания, процесс подготовки к занятиям, характер проведения свободного времени, каникулярные поездки на экскурсии в крупные города [Денисова, Лю-Ку-Тан, 2018г]. Неотъемлемой частью повседневной жизни воспитанников и преподавателей учительского института было здание, история которого также восстанавливается современными учёными [Денисова, Лю-Ку-Тан, 2018б].

Городское училище при Белгородском учительском институте. На сегодняшний день также одним из рассматриваемых аспектов в рамках исследования истории Белгородского учительского института стала история открытого при нём для практических занятий воспитанников городского училища. Учёными рассмотрены правила приема и программа обучения в городском училище, процесс открытия, реконструирован процесс подготовки, проведения и анализа занятий, проведенных воспитанниками учительского института, а также опубликована информация о сохранившемся в фондах музея истории Белгородского государственного национального исследовательского университета аттестате выпускника 1901 г. В.И. Першина [Денисова, Лю-Ку-Тан, 2017в, г]. В целом проанализировано взаимодействие данных учебных заведений, идентифицированы выпускники Белгородского учительского института, которые служили учителями в городском училище: Е.М. Подтягин, И.Т. Иглин, Д.И. Черняков, И.П. Кулегаев, А.И. Панов» [Денисова, Лю-Ку-Тан, 2018а, с. 80].

Наряду с научными публикациями, посвященными истории Белгородского учительского института, результаты научно-исследовательской деятельности нашли отражения в экспозиции музея истории Белгородского государственного национального исследовательского университета, где в связи со 140-летним юбилеем учебного заведения была создана новая постоянная экспозиция «Белгородский учительский институт 1876-1919 гг.» [Денисова, Лю-Ку-Тан, 2017а]. В ней представлены восстановленные биографии шести директоров, их портретные фотографии, репринтные воспроизведения прижизненных изданий их научных трудов, списки преподавателей, их фотографии, цифровые копии работ преподавателя рисования и черчения Ю.И. Феддерса, а также списки выпускников и медаль «Достойному», которой награждали лучших воспитанников учительского института [Денисова, 2018]. 
Кроме постоянной экспозиции по результатам научной работы были представлены и временные выставки, посвященные юбилеям директоров учебного заведения «160 лет со дня рождения директоров Белгородского учительского института А.К. Димитриу и П.А. Дьяконова», а также «160 лет со дня рождения директора Белгородского учительского института Ф.Е. Пактовского» [Денисова, Лю-Ку-Тан, 2018в].

Таким образом, в современной исторической науке Белгородский учительский институт является одним из наиболее исследованных учебных заведений данного типа европейской части Российской Империи. Результаты научных исследований опубликованы в 32 научных статьях и кратких исторических справках, а также отражены в экспозиции музея истории НИУ «БелГУ». Историография 2000-х годов посвящена восстановлению исторического развития Белгородского учительского института с 1876 по 1919 гг. Увеличение исследовательского интереса и расширение тематики исследований по истории Белгородского учительского института наблюдается с середины 2010-х годов. Все проанализированные исследования разделены на следующие тематические блоки: нормативноправовая база учительских институтов, процесс открытия учительского института в Белгороде, директора, преподавательский состав и выпускники Белгородского учительского института, повседневная жизнь воспитанников и городское училище при учительском институте.

\section{Список литературы}

1. Болгова А.М. 2001. К истории создания Белгородского учительского института: документы и материалы. Из истории образования на Белгородчине. Вып. 1. Белгород, 100.

2. Болгова А.М. 2002. К истории учреждения Белгородского учительского института. Научные ведомости БелГУ. Серия Педагогика, 17 (2): 239-249.

3. Денисова И.В. 2013. Из истории становления Белгородского учительского института (Харьковский учебный округ). В кн.: Історичні регіони України: минуле та сучасність. Материалы международной конференции» (Харьков, 28-29 октября 2013 г.). Харьков: 173-176.

4. Денисова И.В. 2016. О выставочных проектах университетского музея. В кн.: Научнометодическое сопровождение образовательных программ в области искусства. Материалы международной научно-практической конференции (г. Белгород, 21-22 октября 2016 года). Белгород, ИПЦ «ПОЛИТЕРРА»: 72-73.

5. Денисова И.В. 2016. Педагог Алексей Димитриу (1857-1925) - первый византинист Белгорода. В кн.: Империя ромеев во времени и пространстве: центр и периферия. Тезисы докладов XXI Всероссийской научной сессии византинистов. М.; Белгород, ООО «Эпицентр»: 75-77.

6. Денисова И.В. 2018. Научно-исследовательская деятельность музея истории Белгородского государственного национального исследовательского университета. Жизнь земли. Междисциплинарный научно-практический журнал, 40 (1): 77-83.

7. Денисова И.В., Лю-Ку-Тан В.А. 2016. Программа поступления в Белгородский учительский институт по Закону Божиему в экспозиции музея истории НИУ «БелГУ». Под ред. иерея Ярослава Манохина. В кн.: 1917-2017: уроки столетия: материалы ежегодных Митрофановских церковно-исторических чтений. Воронеж, Издательский дом ВГУ. Вып. I: 56-60.

8. Денисова И.В., Лю-Ку-Тан В.А. 2017. Белгородский учительский институт в экспозиции музея истории НИУ «БелГУ». В кн.: Национальное культурное наследие России: региональный аспект. Материалы V Всерос. науч.-практ. конф. Самара, Самар. гос. ин-т культуры: 274-278.

9. Денисова И.В., Лю-Ку-Тан В.А. 2017. К вопросу о поступлении в Белгородский учительский институт и городское училище при нем. В кн.: Традиционные культуры народов мира: история, интерпретация, восприятие. Материалы международной научно-практической конференции (Белгород, 18 ноября 2016 г.). Белгород, ИПЦ «Политерра»: 45-48.

10. Денисова И.В., Лю-Ку-Тан В.А. 2017. К истории городского училища при Белгородском учительском институте в конце XIX - начале XX века. В кн.: Молодёжь - науке 2017. Материалы молодёжных научно-практических конференций Псковского государственного университета по итогам научно-исследовательской работы в 2016-2017 учебном году. Псков, Псковский государственный университет, 1 (1): 210-213. 
11. Денисова И.В., Лю-Ку-Тан В.А. 2018. Городское училище при Белгородском учительском институте в конце XIX - начале XX века. Плотникова. В кн.: Карамзинские чтения. Материалы II Всероссийской научной конференции (Белгород, 15 декабря 2017 г.). Белгород, ИД «Белгород» НИУ «БелГУ»: 77-80.

12. Денисова И.В., Лю-Ку-Тан В.А. 2018. К вопросу о здании Белгородского учительского института. Сост. Н.М. Гончаренко. В кн: Интеграция как базовый фактор создания и развития социокультурного пространства города. Материалы Международной научно-практической конференции (Белгород, 7-8 декабря 2017 г.). Белгород, КОНСТАНТА: 32-35.

13. Денисова И.В., Лю-Ку-Тан В.А. 2018. Персоналии Белгородского учительского института в фонде музея истории НИУ «БелГУ»: реконструкция и экспонирование. В кн.: VIII Страховские чтения: Николай Николаевич Страхов и его собеседники в мире архивов, музеев и библиотек (к 190-летию со дня Рождения Н.Н. Страхова. Материалы Всероссийской научнопрактической конференции (с международным участием) (Белгород, 21-23 ноября 2018 г.). Белгород, ИД «Белгород»: 193-199.

14. Денисова И.В., Лю-Ку-Тан В.А. 2018. Повседневная жизнь воспитанников Белгородского учительского института. Под об. ред. В.А. Вермеенко. В кн.: Частное и общественное в повседневной жизни населения России: история и современность. Материалы международной научно-практической конференции. СПб., Культурно-просветительское товарищество: 415-420.

15. Денисова И.В., Лю-Ку-Тан В.А. 2018. Преподаватели Закона Божьего в Белгородском учительском институте в конце XIX - начале XX века. Научный результат. Серия: Социальные и гуманитарные исследования, 4 (2): 33-44. DOI: 10.18413/2408-932X-2018-4-2-0-3.

16. Денисова И.В., Лю-Ку-Тан В.А. 2019. Белгород и Белгородский учительский институт в творчестве И.Д. Василенко. В кн.: Природно-географические факторы в повседневной жизни населения России: история и современность (региональный аспект). Материалы международной научной конференции (Санкт-Петербург, 14-16 марта 2019 г.). Санкт-Петербург, Культурнопросветительское товарищество: 172-177.

17. Денисова И.В., Лю-Ку-Тан В.А. 2019. Выпускники Белгородского учительского института в экспозиции музея истории Белгородского государственного национального исследовательского университета. Жизнь Земли: Междисциплинарный научно-практический журнал, 41 (1): 54-60.

18. Денисова И.В., Лю-Ку-Тан В.А. 2019. К вопросу о подготовке и профессиональной деятельности воспитанников Белгородского учительского института. В кн.: Белгородский диалог 2018. Проблемы филологии, всеобщей и отечественной истории: Материалы Х Международного молодежного научного форума (Белгород, 18-23 апреля 2018 г.). Белгород, ИД «Белгород» НИУ «БелГУ»: 163-166.

19. Дятченко Л.Я. 2007. Белгородскому государственному университету 130 лет. Высшее образование в России, 3: 86-92.

20. Золотая книга выпускников. Электронная книга. URL: http://alumni.bsu.edu.ru/alumni/gold-book/book/\#p=10 (дата обращения: 20 августа 2020).

21. Костылева Е.В. 2020. Профессиональная подготовка в Феодосийском учительском институте (1874-1918). Вестник Марийского государственного университета, 14 (1) (37): 24-32. DOI: 10.30914/2072-6783-2020-14-1-24-32.

22. Кочурина С.А. 2005. Учительские институты Западной Сибири и их роль в подготовке педагогических кадров (1902-1920 гг.). Автореф. дис. ... канд. ист. наук. Томск, 26.

23. Лимаров А.И., Патлань Ю.В. 2015. Художник Юлий Феддерс: в поисках новых фактов биографии. RELGA Научно-культурологический журнал. 7 (295). URL: http://www.relga.ru/Environ/WebObjects/tgu-

www.woa/wa/Main?level1=main\&level2=articles\&textid=4253 (дата обращения: 20 августа 2020).

24. Мамаева Т.П. 2016. Из истории развития высшего педагогического образования на Белгородчине (к 140-летию основания НИУ «БелГУ»). Современные тенденции развития науки и технологий, 5: 78-83.

25. Московкин В.М. 2014. Белгородский учительский институт: директора, преподаватели и выпускники. Научный результат. Серия «Социальные и гуманитарные исследования». 2 (2): 29-41. 
26. Московкин В.М. 2014. Забытый деятель народного образования Курской и Воронежской губерний А.К. Димитриу как известный византинист. Научные ведомости Белгородского государственного университета. Серия: История. Политология, 21 (192): 101-105.

27. Московкин В.М. 2014. О крупном деятеле народного образования юга России Александре Федоровиче Комарове (1842-1918). Научные ведомости Белгородского государственного университета. Серия: Гуманитарные науки, 20 (191): 204-211.

28. Московкин В.М. 2014. Очерки о дореволюционных директорах Белгородского учительского института. В кн.: Сучасні проблеми науки та освіти: матеріали 14 міжнар. міждисциплінар. науч.-практ. конф. Харків. нац. ун-т ім. В.Н. Каразіна: 35-48.

29. Московкин В.М. 2016. Очерки о творческой деятельности четырех директоров белгородского учительского института. Научный результат. Серия: Социальные и гуманитарные исследования, 2 (3): 22-43. DOI: 10.18413/2408-932X-2016-2-3-22-43.

30. Московкин В.М. 2017. О крупном деятеле народного образования Курской и Воронежской губерний А.К. Димитриу. Научный результат. Социальные и гуманитарные исследования, 3 (4): 30-48. DOI: 10.18413/2408-932X-2017-3-4-30-48.

31. Московкин В.М., Садовски М.В. 2017. Роль учебного пособия П.Е. Рощина «Очерк главнейших практических положений педагогики, дидактики и методики, примененной к учебным предметам начального образования» в системе дореволюционного российского образования. Almamater (Вестник высшей школы), 8: 114-118. DOI: 10.203339/AM.08-17.114.

32. Московкин В.М., Садовски М.В. 2018. О вкладе бывшего директора Белгородского и Воронежского учительских институтов А.К. Димитриу (1857-1925) в византинистику. Вестник Тамбовского университета. Серия: Гуманитарные науки, 23 (171): 115-123. DOI: 10.20310/18100201-2018-23-1(171)-115-123.

33. Московкин В.М., Шатохин И.Т. 2017. Выпускник Белгородского учительского института 1897 г. Рыбалкин Михаил Михайлович: биография и творчество. Научный результат. Серия: Социальные и гуманитарные исследования, 3 (1): 48-58. DOI: 10.18413/2408-932X-2017-3$1-48-58$.

34. Мустафина Ф.З., Корнилова И.В., Магсумов Т.А. 2014. У истоков педагогического образования в Татарстане: Казанский учительский институт (1876-1918). В мире научных открытий. 11-2 (59): 871-882.

35. Новый этап в развитии вуза 2006-2016 гг. 2016. Под общей редакцией О.Н. Полухина. Белгород, ИД «Белгород» НИУ «БелГУ», 404.

36. Прокофьева Е.Ю. Страницы истории Белгородского учительского института (1876-1917 годы) 1999. В кн: Белгородская область вчера и сегодня (к 45-летию образования области). Материалы региональной научно-практической конференции. Белгород: 51-54.

37. Рощин П.Е. 2016. (репр. изд. 1907 г.). Очерк главнейших практических положений педагогики, дидактики и методики, примененной к учебным предметам начального образования; предисл. и очерк творческой деятельности В.М. Московкина. Белгород, ИД Белгород, 210.

38. Терещенко Д.А. 2016. Учительские институты в системе профессионального образования России во второй половине XIX - начале XX века (на примере Белгородского учительского института). Известия Юго-Западного Государственного Университета, 19 (2): 149-158.

39. Шагеева М.Ш. 2014. Учительские институты на Южном Урале в конце XIX - первой половине ХХ в. Автореф. дис. ... канд. ист. наук. Уфа, 22.

40. Шилов А.И. 2014. Содержание образования в учительских институтах Восточной Сибири в начале XX в. Вестник Красноярского государственного педагогического университета им. В.П. Астафьева, 4 (30): 102-103.

\section{References}

1. Bolgova A.M. 2001. K istorii sozdaniya Belgorodskogo uchitel'skogo instituta: dokumenty i materialy. Iz istorii obrazovaniya na Belgorodchine [On the history of the creation of the Belgorod Teachers' Institute: documents and materials. From the history of education in the Belgorod region]. Vol. 1. Belgorod, 100 p. (in Russian).

2. Bolgova A.M. 2002. K istorii uchrezhdeniya Belgorodskogo uchitel'skogo institute [On the History of the Foundation: Belgorod Teachers' Training Institute]. Belgorod State University Scientific Bulletin. Pedagogy 17 (2): 239-249 (in Russian). 
3. Denisova I.V. 2013. Iz istorii stanovleniya Belgorodskogo uchitel'skogo instituta (Khar'kovskiy uchebnyy okrug) [From the history of the formation of the Belgorod Teachers' Institute (Kharkov educational district)]. In: Istorichni regioni Ukraïni: minule ta suchasnist'. Materialy mezhdunarodnoy konferentsii [The Historical Regions of Ukraine: Passed and Passed. Materials of the international conference] (Kharkov, October 28-29, 2013). Kharkov: 173-176 (in Russian).

4. Denisova I.V. 2016. O vystavochnykh proektakh universitetskogo muzeya [About exposition projects of the university museum]. In: Nauchno-metodicheskoe soprovozhdenie obrazovatel'nykh programm v oblasti iskusstva. Materialy mezhdunarodnoy nauchno-prakticheskoy konferentsii [Scientific and methodological support of educational programs in the field of art. Materials of the international scientific-practical conference] (Belgorod, 21-22 October, 2016). Belgorod, IPTs «POLITERRA»: 72-73.

5. Denisova I.V. 2016. Pedagog Aleksey Dimitriu (1857-1925) - pervyy vizantinist Belgoroda [Teacher Alexei Dimitriu (1857-1925) - the first Byzantine scholar of Belgorod]. In: Tezisy dokladov XXI Vserossiyskoy nauchnoy sessii vizantinistov «Imperiya romeev vo vremeni i prostranstve: tsentr i periferiya» [Abstracts of the XXI All-Russian Scientific Session of Byzantinists «The Empire of the Romans in Time and Space: Center and Periphery»]. Moscow; Belgorod: 75-77 (in Russian).

6. Denisova I.V. 2018. Nauchno-issledovatel'skaya deyatel'nost' muzeya istorii Belgorodskogo gosudarstvennogo natsional'nogo issledovatel'skogo universiteta [Scientific research activity of the history Museum of Belgorod National Research University]. Zhizn' Zemli [the Life of the Earth]. 4 (1): 77-83 (in Russian).

7. Denisova I.V., Lyu-Ku-Tan V.A. 2016. Programma postupleniya v Belgorodskiy uchitel'skiy institute po Zakonu Bozhiemu v ekspozitsii muzeya istorii NIU «BelGU» [The program of admission to the Belgorod Teachers' Institute according to the Law of God in the exposition of the Museum of History of the Belgorod National Research University]. Yaroslav Manokhin. In: 1917-2017: uroki stoletiya: materialy ezhegodnykh Mitrofanovskikh tserkovno-istoricheskikh chteniy [1917-2017: Lessons of the Century: Materials of the Annual Mitrofanov Church Historical Readings]. Voronezh, Izdatel'skiy dom VGU. 1: 56-60 (in Russian).

8. Denisova I.V., Lyu-Ku-Tan V.A. 2017. Belgorod teacher training Institute in the Museum of history «BelSU». In: Natsional'noe kul'turnoe nasledie Rossii: regional'nyy aspekt. Materialy V Vserosciyskoy nauchno-prakticheskoy konferentsii [National cultural heritage of Russia: regional aspect. Materials of the V All-Russian Scientific and Practical Conference]. Samara, Samarskiy gosudarstvennyy institute kul'tury: 274-278 (in Russian).

9. Denisova I.V., Lyu-Ku-Tan V.A. 2017. K voprosu o postuplenii v Belgorodskiy uchitel'skiy institut i gorodskoe uchilishche pri nem [On the question of admission to the Belgorod Teachers' Institute and the town school]. In: Traditsionnye kul'tury narodov mira: istoriya, interpretatsiya, vospriyatie. Materialy mezhdunarodnoy nauchno-prakticheskoy konferentsii [Traditional cultures of the peoples of the world: history, interpretation, perception. Materials of the international scientific and practical conference] (Belgorod, 18 November, 2016). Belgorod, IPTs «Politerra»: 45-48 (in Russian).

10. Denisova I.V., Lyu-Ku-Tan V.A. 2017. K istorii gorodskogo uchilishcha pri Belgorodskom uchitel'skom institute $\mathrm{v}$ kontse XIX - nachale XX veka [On the history of the town school at the Belgorod Teachers' Institute in the late XIX - early XX century]. In: Molodezh' - nauke 2017. Materialy molodezhnykh nauchno-prakticheskikh konferentsiy Pskovskogo gosudarstvennogo universiteta po itogam nauchno-issledovatel'skoy raboty v 2016-2017 uchebnom godu [Youth - Science 2017. Materials of youth scientific and practical conferences of Pskov State University on the basis of research work in the 2016-2017 academic year]. Pskov, Pskovskiy gosudarstvennyy universitet, 1 (1): 210-213 (in Russian).

11. Denisova I.V., Lyu-Ku-Tan V.A. 2018. Gorodskoe uchilishche pri Belgorodskom uchitel'skom institute $v$ kontse XIX - nachale XX veka [Town school at the Belgorod Teachers' Institute in the late XIX - early XX century comparative]. Plotnikova. In: Karamzinskie chteniya. Materialy II Vserossiyskoy nauchnoy konferentsii [Karamzin readings. Materials of the II All-Russian Scientific Conference]. (Belgorod, 15 December, 2017). Belgorod, Izdatel'skiy dom «Belgorod» NRU «BelSU»: 77-80 (in Russian).

12. Denisova I.V., Lyu-Ku-Tan V.A. 2018. K voprosu o zdanii Belgorodskogo uchitel'skogo instituta [On the first building Belgorod Teachers' Institute]. In: Integratsiya kak bazovyy factor sozdaniya i razvitiya sotsiokul'turnogo prostranstva goroda. Materialy Mezhdunarodnoy nauchnoprakticheskoy konferentsii [Integration as a basic factor in the creation and development of the socio- 
cultural space of the city. Materials of the International Scientific and Practical Conference] (Belgorod, 7-8 December, 2017). Belgorod. KONSTANTA: 32-35 (in Russian).

13. Denisova I.V., Lyu-Ku-Tan V.A. 2018. Personalii Belgorodskogo uchitel'skogo instituta v fonde muzeya istorii NIU «BelGU»: rekonstruktsiya i eksponirovanie [Personell of the Belgorod Teaching Institute in the fund of the Museum of History of the Belgorod National Research University University: reconstruction and exposition]. In: VIII Strakhovskie chteniya: Nikolay Nikolaevich Strakhov i ego sobesedniki v mire arkhivov, muzeev i bibliotek (k 190-letiyu so dnya rozhdeniya N.N. Strakhova. Materialy Vserossiyskoy nauchno-prakticheskoy konferentsii (s mezhdunarodnym uchastiem) [VIII Strakhov readings: Nikolai Nikolaevich Strakhov and his interlocutors in the world of archives, museums and libraries (on the occasion of the 190th anniversary of the birthday of N.N. Strakhov. Materials of the All-Russian Scientific and Practical Conference (with international participation)] (Belgorod, 21-23 November, 2018). Belgorod, Izdatel'skiy dom «Belgorod»: 193-199 (in Russian).

14. Denisova I.V., Lyu-Ku-Tan V.A. 2018. Povsednevnaya zhizn' vospitannikov Belgorodskogo uchitel'skogo institute [The daily life of pupils of the Belgorod Teachers' Institute in the late XIX - early XX century]. Private and public in daily life of the population of Russia: history and present time (regional aspect). Collection of materials of the international scientific conference. Under the general editorship of prof. V.A. Veremenko, editor-in-chief S.V. Stepanov. Saint Petersburg: 415-420 (in Russian).

15. Denisova I.V., Lyu-Ku-Tan V.A. 2018. Prepodavateli Zakona Bozh'ego v Belgorodskom uchitel'skom institute v kontse XIX - nachale XX veka [Teachers of the law of God in the Belgorod Teacher's Training Institute at the end of the 19th and the beginning of the 20th century]. Research Result. Social Studies and Human Humanities Series, 4 (2): 33-44. DOI: 10.18413/2408-932X-2018-4-2-0-3 (in Russian).

16. Denisova I.V., Lyu-Ku-Tan V.A. 2019. Belgorod i Belgorodskiy uchitel'skiy institut v tvorchestve I.D. Vasilenko [Belgorod and Belgorod Teaching Institute in the works of I.D. Vasilenko]. In: Natural and geographical factors in the everyday life of Russian population: history and modernity (regional aspect). Collection of materials of the international scientificconference (Saint Petersburg, 14-16 March, 2018) / Under general editorship of Full Professor V.A. Veremenko, [editor-in-chief S.V. Stepanov]. Saint Petersburg: 172-177 (in Russian).

17. Denisova I.V., Lyu-Ku-Tan V.A. 2019. Vypuskniki Belgorodskogo uchitel'skogo instituta v ekspozitsii muzeya istorii Belgorodskogo gosudarstvennogo natsional'nogo issledovatel'skogo universiteta [Graduates of the Belgorod teacher's training institute in the exhibition at the history Museum of Belgorod State National Research University]. Zhizn' Zemli [the Life of the Earth], 41 (1): 54-60 (in Russian).

18. Denisova I.V., Lyu-Ku-Tan V.A. 2019. K voprosu o podgotovke i professional'noy deyatel'nosti vospitannikov Belgorodskogo uchitel'skogo instituta [On the question of the training and professional activity of the teachers of the Belgorod Educational Institute]. In: Belgorodskiy dialog 2018. Problemy filologii, vseobshchey i otechestvennoy istorii. Materialy X Mezhdunarodnogo molodezhnogo nauchnogo foruma [Belgorod Dialogue - 2018. Problems of Philology, General and National History: Materials of the X International Youth Scientific Forum] (Belgorod, 18-23 April 2018). Belgorod, Izdatel'skiy dom «Belgorod»: 163-166 (in Russian).

19. Dyatchenko L.Ya. 2007. Belgorodskomu gosudarstvennomu universitetu 130 let [Belgorod State University is 130 years old]. Vysshee obrazovanie v Rossii. Higher Education in Russia, 3: 86-92 (in Russian).

20. Zolotaya kniga vypusknikov [Gold book of graduates]. Available at: http://alumni.bsu.edu.ru/alumni/gold-book/book/\#p=10 (accessed 20 August 2020) (in Russian).

21. Kostyleva K.V. 2020. Professional'naya podgotovka v Feodosiyskom uchitel'skom institute (1874-1918) [Professional training at Feodosiya Teachers' Institute (1874-1918)]. Vestnik of the Mari State University 14 (1) (37): 24-32. DOI: 10.30914/2072-6783-2020-14-1-24-32 (in Russian).

22. Kochurina S.A. 2005. Uchitel'skie instituty Zapadnoy Sibiri i ikh rol' v podgotovke pedagogicheskikh kadrov (1902-1920 gg.) [Teachers' institutes in Western Siberia and their role in the training of teaching staff (1902-1920)]. Abstract. dis. ... cand. hist. sciences. Tomsk, 26 (in Russian).

23. Limarov A.I., Patlan' Yu.V. 2015. Khudozhnik Yuliy Fedders: v poiskakh novykh faktov biografii [Artist Julius Fedders: In Search of New Biographical Facts]. RELGA Nauchnokul'turologicheskiy zhurnal. 7 (295). URL: http://www.relga.ru/Environ/WebObjects/tguwww.woa/wa/Main?level1=main\&level2=articles\&textid=4253 (accessed 20 August, 2020) (in Russian)

24. Mamaeva T.P. 2016. Izistorii razvitiya vysshego pedagogicheskogo obrazovaniya na Belgorodchine (k 140-letiyu osnovaniya NIU «BelGU») [From the history of the development of higher 
pedagogical education in the Belgorod region (to the 140th anniversary of the foundation of the National Research University «BelSU»)]. Sovremennye tendentsii razvitiya nauki i tekhnologiy, 5: 78-83 (in Russian).

25. Moskovkin V.M. 2014. Belgorodskiy uchitel'skiy institut: direktora, prepodavateli i vypuskniki [Belgorod teachers' training institute: the directors, teachers and graduates]. Research Result. Social Studies and Human Humanities Series, 1 (2): 29-41 (in Russian).

26. Moskovkin V.M. 2014. Zabytyy deyatel' narodnogo obrazovaniya Kurskoy i Voronezhskoy guberniy A.K. Dimitriu kak izvestnyy vizantinist [The forgotten actor of people education of Kursk and Voronezh provinces F.K. Dimitriu as a well-known Byzantinist]. Belgorod State University Scientific Bulletin. History Political Science. Economics Information technologies, 21 (192): 101-105 (in Russian).

27. Moskovkin V.M. 2014. O krupnom deyatele narodnogo obrazovaniya yuga Rossii Aleksandre Fedoroviche Komarove (1842-1918) [Alexander Fedorovich Komarov (1842-1918) as an outstanding Figure of public Education of Soyth of Russia]. Belgorod State University Scientific Bulletin. Humanities Philology Journalism Pedagogy Psychology, 20 (191): 204-211 (in Russian).

28. Moskovkin V.M. 2014. Ocherki o dorevolyutsionnykh direktorakh Belgorodskogo uchitel'skogo instituta [Essays on pre-revolutionary directors of Belgorod teachers institute. In: Actual problems of science and education]. In: Modern sciences and education: materials of the $14^{\text {th }}$ international interdisciplinary scientific and practical conference. Kharkov, V.N. Karazin Kharkiv National University: 35-48 (in Russian).

29. Moskovkin V.M. 2016. Ocherki o tvorcheskoy deyatel'nosti chetyrekh direktorov belgorodskogo uchitel'skogo instituta [Essays about creative activities of four directors of Belgorod Teacher's Institute]. Research Result. Social Studies and Human Humanities Series, 2 (3): 22-43. DOI: 10.18413/2408-932X-2016-2-3-22-43 (in Russian).

30. Moskovkin V.M. 2017. O krupnom deyatele narodnogo obrazovaniya Kurskoy i Voronezhskoy guberniy A.K. Dimitriu [About Aleksey Dimitriu - an outstanding figure of the public education of Kursk and Voronezh provinces]. Research Result. Social Studies and Human Humanities Series, 3 (4): 30-48. DOI: 10.18413/2408-932X-2017-3-4-30-48 (in Russian).

31. Moskovkin V.M., Sadovski M.V. 2017. Rol' uchebnogo posobiya P.E. Roshchina «Ocherk glavneyshikh prakticheskikh polozheniy pedagogiki, didaktiki i metodiki, primenennoy $\mathrm{k}$ uchebnym predmetam nachal'nogo obrazovaniya» $\mathrm{v}$ sisteme dorevolyutsionnogo rossiyskogo obrazovaniya [The Role of Educational Text - Book by P.E. Roschtschin «Essay of principal practical provisions of pedagogy, didactics and methodology, applicable to academic subjects in primary education»]. Alma mater (Vestnik Vysshey Shkoly), 8: 114-118. DOI: 10.203339/AM.08-17.114 (in Russian).

32. Moskovkin V.M., Sadovski M.V. 2018. O vklade byvshego direktora Belgorodskogo i Voronezhskogo uchitel'skikh institutov A.K. Dimitriu (1857-1925) v vizantinistiku [About the contribution of the former director of Belgorod and Voronezh Teachers' Institutes A.K. Dimitriu (1857-1925) in the Byzantine studies]. Tambov University Review. Series: Humanities, 23 (171): 115-123. DOI: 10.20310/1810-0201-2018-23-1(171)-115-123 (in Russian).

33. Moskovkin V.M., Shatokhin I.T. 2017. Vypusknik Belgorodskogo uchitel'skogo instituta 1897 g. Rybalkin Mikhail Mikhaylovich: biografiya i tvorchestvo [Mikhail Rybalkin, a 1897 graduate of Belgorod Teachers' Institute: biography and achievements]. Research Result. Social Studies and Human Humanities Series, 3 (1): 48-58. DOI: 10.18413/2408-932X-2017-3-1-48-58 (in Russian).

34. Mustafina F.Z., Kornilova I.V., Magsumov T.A. 2014. U istokov pedagogicheskogo obrazovaniya $v$ tatarstane: Kazanskiy uchitel'skiy institut (1876-1918) [At the origins of pedagogical education in Tatarstan: Kazan Teacher's Institute (1876-1918)]. In the World of Scientific Discoveries. 11-2 (59): 871-882 (in Russian).

35. Novyy etap v razvitii vuza 2006-2016 gg. [A new stage in the development of the university 2006-2016]. 2016. Pod obshchey redaktsiey O.N. Polukhina. Belgorod, Izdatel'skiy dom «Belgorod» NRU «BelSU», 404 (in Russian).

36. Prokof'eva E.Yu. Stranitsy istorii Belgorodskogo uchitel'skogo instituta (1876-1917 gody) 1999 [Pages of the history of the Belgorod Teachers' Institute (1876-1917)]. In: Belgorodskaya oblast' vchera i segodnya (k 45-letiyu obrazovaniya oblasti). Materialy regional'noy nauchno-prakticheskoy konferentsii [Belgorod region yesterday and today (to the 45th anniversary of the region). Materials of the regional scientific and practical conference]. Belgorod: 51-54 (in Russian).

37. Roshchin P.E. 2016. Ocherk glavneyshikh prakticheskikh polozheniy pedagogiki, didaktiki i metodiki, primenennoy k uchebnym predmetam nachal'nogo obrazovaniya [Essay of key practical ideas 
of pedagogic, didactic and methodic, applied to studying subjects of primary education]; predislovie i ocherk tvorcheskoy deyatel'nosti V.M. Moskovkina. Belgorod, ID Belgorod, 210 (in Russian).

38. Tereshchenko D.A. 2016. Uchitel'skie instituty v sisteme professional'nogo obrazovaniya Rossii vo vtoroy polovine XIX - nachale XX veka (na primere Belgorodskogo uchitel'skogo instituta) [Teacher Training Institute in vocational education in Russia in the second half of XIX - early XX century (for example, Belgorod teachers' institute)]. Proceedings of the Southwest State University, 19 (2): 149-158 (in Russian).

39. Shageeva M.Sh. 2014. Uchitel'skie instituty na Yuzhnom Urale v kontse XIX - pervoy polovine XX v. [Teachers' institutes in the South Urals at the end of the XIX - the first half of the XX century]. Abstract. dis. ... cand. hist. sciences. Ufa, 22 (in Russian).

40. Shilov A.I. 2014. Soderzhanie obrazovaniya v uchitel'skikh institutakh Vostochnoy Sibiri v nachale XX v. [The syllabus of Teachers' Institutes in Eastern Siberia at the beginning of the XX century]. Bulletin of Krasnoyarsk State Pedagogical University named after V.P. Astafiev, 4 (30): 102-103 (in Russian).

\section{ИНФОРМАЦИЯ ОБ АВТОРЕ}

Лю-Ку-Тан Виктория Александровна, аспирант кафедры российской истории и документоведения Белгородского государственного национального исследовательского университета, г. Белгород, Россия

\section{INFORMATION ABOUT THE AUTHOR}

Viktoria A. Lyu-Ku-Tan, Postgraduate Student, Department of Russian History and Documentation, Belgorod State National Research University, Belgorod, Russia 